\title{
Salivary CGRP as diagnostic and migraine attack phase monitor biomarker:
}

\section{CGRP (in)dependent attacks}

Alicia Alpuente, MD 1,2; Victor J Gallardo, MSc 2; Laila Asskour, MLT 2; Edoardo Caronna, MD ${ }^{1,2}$; Marta Torres-Ferrus, MD, PhD 1,2; Patricia Pozo-Rosich, MD, PhD 1,2

1 Headache Unit, Neurology Department, Vall d'Hebron University Hospital, Barcelona, Spain.

2 Headache and Neurological Pain Research Group, Vall d'Hebron Research Institute, Departament de Medicina, Universitat Autònoma de Barcelona, Barcelona, Spain.

Corresponding Author: Patricia Pozo-Rosich. 119-129 Passeig de la Vall d'Hebron.

Barcelona, Spain, 08035. Phone: 0034934893 000.ppozo@vhebron.net 
medRxiv preprint doi: https://doi.org/10.1101/2020.11.18.20233841; this version posted November 18, 2020. The copyright holder for this preprint (which was not certified by peer review) is the author/funder, who has granted medRxiv a license to display the preprint in It is made available under a CC-BY-NC-ND 4.0 International license .

\section{ABSTRACT}

Objective: To assess saliva as a substrate to measure CGRP by comparing interictal levels of CGRP in patients with episodic migraine and controls; and to evaluate saliva CGRP temporal profile during migraine attacks.

Methods: This prospective observational study included women with episodic migraine and healthy controls. Participants collected daily saliva samples for 30 consecutive days and 3 additional ones during migraine attacks. 4 timepoints were considered: interictal (72h headache-free), preictal (PRE-24h before the attack), ictal (0h,2h,8h), postictal (POST-24h after the attack). CGRP levels were quantified by ELISA.

Results: 35 women (22 patients, 13 controls) were included. Statistically significant differences were found in interictal salivary levels of CGRP between patients and controls (median[IQR]: 98.0 [86.7] vs. 42.2 [44.7] pg/mL; $p=0.010$ ). An increase in CGRP levels during migraine attacks was detected (median[IQR]: preictal 113.5 [137.8], Oh 164.6 [204.5], 2h 101.7 [159.1], 8h 82.6 [166.2], postictal 79.6 [124.3] pg/ml; p<0.001). Patients were classified as having CGRP-dependent (80.0\%) and non-CGRP dependent migraine attacks (20.0\%) according to the magnitude of change between preictal and ictal phase (Oh). Accompanying symptoms were different depending on the type of attack. In the longitudinal analysis, we observed that the amount of CGRP measured during attacks were phase dependent and it was influenced by the frequency of monthly headache days $(p=0.02)$.

Interpretation: Patients with episodic migraine have higher interictal salivary levels of CGRP than controls. These levels usually increase during a migraine attack, however, not 
medRxiv preprint doi: https://doi.org/10.1101/2020.11.18.20233841; this version posted November 18, 2020. The copyright holder for this preprint (which was not certified by peer review) is the author/funder, who has granted medRxiv a license to display the preprint in It is made available under a CC-BY-NC-ND 4.0 International license

every attack is CGRP-dependent, which in turn, might explain different underline pathophysiology and response to acute and preventive treatment. 
medRxiv preprint doi: https://doi.org/10.1101/2020.11.18.20233841; this version posted November 18, 2020. The copyright holder for this preprint (which was not certified by peer review) is the author/funder, who has granted medRxiv a license to display the preprint in It is made available under a CC-BY-NC-ND 4.0 International license

\section{INTRODUCTION}

Biomarkers are indicators of a normal biological or pathological process and they have great value in clinical practice and research ${ }^{1}$. Being migraine the most prevalent and disabling neurological disease ${ }^{2}$, specific biomarkers have yet not been validated ${ }^{3,4}$, reflecting the dynamism and complexity of the disease. However, the most promising candidate of becoming a migraine biomarker is currently calcitonin gene related peptide (CGRP) due to its clear implication in migraine pathophysiology ${ }^{5}$, underpinned by the arrival of therapies targeting CGRP pathways ${ }^{6}$.

Saliva as substrate to study biomarkers is a worthwhile approach because its collection is noninvasive, inexpensive and neuropeptides could be monitored because samples can be repeatedly obtained from subjects ${ }^{7}$. The feasibility of CGRP detection in human saliva has been previously demonstrated and used as a way to study trigeminovascular activation in migraine ${ }^{8-13}$. CGRP has been considered as a potential diagnostic $8,14,15$ and treatment predictive biomarker in acute and preventive migraine treatment ${ }^{13,15-17}$. Nonetheless, we found a large variability between CGRP levels across studies, probably due to methodological differences such as saliva collection techniques, type of assay and heterogeneous study population, making the results not comparable.

Biomarker assay validation before introduction in clinical practice is essential in order to get reliable results and assay information is mandatory in research reports on novel biomarker candidates ${ }^{18}$. A standardized approach to saliva collection and analysis is needed in order to be able to use it as a valuable resource to gain scientific and diagnostic information in migraine. Therefore, the objectives of this study were: 1) to define a highly 
medRxiv preprint doi: https://doi.org/10.1101/2020.11.18.20233841; this version posted November 18, 2020. The copyright holder for this preprint (which was not certified by peer review) is the author/funder, who has granted medRxiv a license to display the preprint in It is made available under a CC-BY-NC-ND 4.0 International license

specific technical protocol to measure salivary CGRP and, 2) to compare interictal salivary CGRP levels in episodic migraine (EM) patients with healthy controls (HC), as well as, 3) to assess the temporal profile of CGRP during migraine attacks.

\section{METHODS}

\section{Participants and study design}

This is a prospective longitudinal exploratory study. Participants were recruited from the outpatient headache clinic and carefully interviewed by a headache specialist. Recruitment period was from March 2018 to November 2019.

In order to obtain a homogeneous sample, HC were women between 18-65 years old with no previous migraine or headache history. Patients fulfilled the criteria for EM with or without aura, according to the International Classification of Headache Disorders (ICHD-3) ${ }^{19}$. Participants with a smoking habit; medical diagnosis of anxiety/depression; medical diagnosis of presence chronic pain disorders; subjects taking medication affecting central nervous system; subjects taking migraine preventive medication in the past year prior to the study or history of any medical condition that could alter saliva content were excluded.

At the screening visit, demographical and clinical data were collected. All participants completed the following Patient Reported Outcome Scales (PROs): Migraine Disability Assessment (MIDAS) 20 and the Headache Impact Test 6 (HIT-6) ${ }^{21}$. Patients also completed the Hospital Anxiety and Depression Scale (HAD A-D) ${ }^{22}$, Perceived Stress Scale 
medRxiv preprint doi: https://doi.org/10.1101/2020.11.18.20233841; this version posted November 18, 2020. The copyright holder for this preprint (which was not certified by peer review) is the author/funder, who has granted medRxiv a license to display the preprint in It is made available under a CC-BY-NC-ND 4.0 International license

(PSS) ${ }^{23}, 12$-item Allodynia Symptom Checklist (ASC-12) ${ }^{24}$, The International Physical Activity Questionnaire (IPAQ), The Pittsburgh Sleep Quality Index (PSQI) ${ }^{25}$ and a PERIODONTAL assessment.

All participants were given detailed verbal and written instructions for saliva collection and they were provided with appropriate material for its collection at home including: pre-labelled tubes; diaries to register sample collection time and menstrual cycle; questionnaires to record migraine attack characteristics such as pain intensity and duration, accompanying symptoms and acute treatment used. During the study, subjects treated their migraine attacks as usual, if they considered they could not tolerate it, with an approval of the investigator at the initial visit (triptans and non-steroidal antiinflammatory drugs were allowed).

\section{Saliva collection}

HC and EM patients collected saliva samples consecutively during a 30-day period (baseline samples). EM patients collected three extra saliva samples in each migraine attack (painful condition samples): $0 \mathrm{~h}, 2 \mathrm{~h}$ and $8 \mathrm{~h}$.

Saliva collection was carried out with the resting unstimulated whole saliva method 7,11 using the following step-by-step indications:

- To collect saliva at the same time of the day, early in the morning, fasting condition.

- Not to eat, drink or brush their teeth before collection.

- To rinse their mouth with water, discarding initial saliva in order to avoid contaminated saliva with debris. 
medRxiv preprint doi: https://doi.org/10.1101/2020.11.18.20233841; this version posted November 18, 2020. The copyright holder for this preprint (which was not certified by peer review) is the author/funder, who has granted medRxiv a license to display the preprint in It is made available under a CC-BY-NC-ND 4.0 International license.

- To collect the fluid by spitting into a sterile tube of $5 \mathrm{~mL}$ for 5 minutes with a minimum quantity of $3 \mathrm{~mL}$. Each tube was used once only.

- Not to use citric acid since it could degrade CGRP.

After collection, all saliva samples were kept in the freezer of participants at $-20{ }^{\circ} \mathrm{C}$ until they were brought in to the laboratory. During transport samples were kept on ice. We kindly asked participants to keep the attack samples in a fridge if they were away from home. Once saliva samples were received at the laboratory they were stored in the freezer at -20 ㅇ.

\section{Plasma collection}

Plasma samples were also collected from each participant on day 1 in order to make a saliva-plasma correlation. It was noted if it was a free pain period (outside of an attack). Samples were collected from the subject's antecubital vein between 8-10 am and transferred to EDTA coated $10.8 \mathrm{mg}$ tubes (BD Vacutainer System, K2E). All samples were centrifuged at $3500 \mathrm{rpm}$ at 4 으 for $15 \mathrm{~min}$ and supernatants were immediately stored at -80 - C until analysis.

\section{Saliva extraction}

Saliva samples were thawed slowly at room temperature and then placed on ice. The samples were centrifuged for 20 minutes at $3500 \mathrm{rpm}-4$ 으, and the supernatant was aliquoted into $1.5 \mathrm{~mL}$ centrifuge sterile tubes and stored at $-80 \circ \mathrm{C}$ or immediately analyzed. Prior to Enzyme-linked Immunosorbent Assay (ELISA), samples were thawed slowly and then centrifuged for 5 minutes at $3500 \mathrm{rpm}$ at room temperature to pellet cellular debris. 
medRxiv preprint doi: https://doi.org/10.1101/2020.11.18.20233841; this version posted November 18, 2020. The copyright holder for this preprint (which was not certified by peer review) is the author/funder, who has granted medRxiv a license to display the preprint in It is made available under a CC-BY-NC-ND 4.0 International license

Samples were stored at $-80 \circ \mathrm{C}$, which helped avoid protein degradation and denaturalization. Moreover, to minimize degradation of unstable antigens, samples were kept in ice, and, repeated freeze-thaw cycles were avoided.

\section{Assay protocol}

The operating procedures for assay performance are exhaustively detailed in assay protocol. CGRP was quantitated using a commercial CGRP sandwich ELISA kit (CUSABIO ${ }^{\circledR}$, CSB-E08210H, detection range: $1.56-100 \mathrm{pg} / \mathrm{ml}$, minimal detectable dose: $0.39 \mathrm{pg} / \mathrm{ml}$ ), following manufacturer's instructions (Wuhan, China). Intra-assay precision and interassay precision is declared with a coefficient of variation (CV) of $<8 \%$, respectively $<10 \%$. Duplicate measurements were performed for each sample. CGRP concentrations were determined from calibration curves using a 4PL fitting as implemented in Analysis software Gen 5 resulting in a fit with R2>0.99 in every case. The final CGRP level of each sample was calculated as the average of the two measurements. An internal validation of the test was performed, ensuring that the ELISA assay used was reliable (quality control was included in the kit).

We found that saliva samples had to be diluted 1:10 with sample diluent, being important to homogenize the sample with the diluent (repeated up-down cycles). In addition, it is extremely important to discard blood contaminated samples. In plasma samples, it is important to discard lipemic and hemolyzed samples. Those samples were not diluted due to the low concentration of CGRP in plasma. 
medRxiv preprint doi: https://doi.org/10.1101/2020.11.18.20233841; this version posted November 18, 2020. The copyright holder for this preprint (which was not certified by peer review) is the author/funder, who has granted medRxiv a license to display the preprint in It is made available under a CC-BY-NC-ND 4.0 International license

CGRP measurements were performed at our laboratory at the Vall d'Hebron Institute of Research, Spain. The immunoassay used did not require CGRP values to be normalized according to saliva volume and amount of total protein but CGRP concentration was corrected by inter and intra-assay coefficients of variability.

In order to analyze CGRP levels over the different migraine phases, we considered 4 timepoints: interictal (median value of 5 consecutive days, for migraine patients when they were headache-free for 72 hours), preictal (pre-24h before the migraine attack), ictal $(0 \mathrm{~h}, 2 \mathrm{~h}, 8 \mathrm{~h})$ and postictal (post-24h after the migraine attack).

\section{Statistics}

Descriptive and frequency statistics were obtained and comparisons made using R v3.6.3. Nominal (categorical) variables were reported as frequencies (percentages) while mean \pm standard deviation (age, disease evolution time, HIT-6 and PSS) or median and interquartile range (Me[IQR]) (MIDAS, HAD Scale and CGRP levels) were reported for continuous variables. Normality assumption of quantitative variables was checked through visual methods (Q-Q plots) and normality tests (Shapiro-Wilk test).

Statistical significance for intergroup variables was assessed by Pearson's chi-square when comparing categorical variables. In the case of having an expected count less than 5 in more than $20 \%$ of cells in the contingency table, Fisher's exact test was used. Linear trend chi-square was considered for ordinal variables. Independent t-test for continuous variables that followed a normal distribution (age and PSS) was used in order to assess differences between migraine patients and healthy controls and, Mann-Whitney $U$ test 
medRxiv preprint doi: https://doi.org/10.1101/2020.11.18.20233841; this version posted November 18, 2020. The copyright holder for this preprint (which was not certified by peer review) is the author/funder, who has granted medRxiv a license to display the preprint in It is made available under a CC-BY-NC-ND 4.0 International license

was used for the rest variables that did not follow any normality assumption (HAD Scales and CGRP basal levels). The degree of association between interictal CGRP levels and clinical variables was computed by Spearman's rank correlation and summarized by Spearman's rho coefficient and related p-values.

We estimated the ictal log2Fold-Change $\left(\log _{2} F C_{\text {ictal }}\right)$ (Eq. 1) in patients with the aim of finding out whether all migraine attacks reflected an incremental change at salivary CGRP level between preictal phase (pre) and ictal phase (0h). Hence, migraine attacks were classified into CGRP dependent (dCGRP) $\left(\log _{2} F C_{\text {ictal }}>0\right)$ or non-CGRP dependent (nCGRP) $\left(\log _{2} F C_{i c t a l} \leq 0\right)$.

$$
\log _{2} F C_{\text {ictal }}=\log _{2}[C G R P]_{\text {attack onset }}-\log _{2}[C G R P]_{\text {premonitory }}
$$

Equation 1. Ictal Fold-Change: Measure concept for the evaluation of the change of the CGRP salivary level between premonitory and the attack onset phases.

Finally, to determine the significance of CGRP intraindividual changes according to patient's migraine phase, we used the nonparametric Friedman test. Moreover, we evaluated the interaction between the migraine phase effect in CGRP concentration with the basal headache frequency ( $\leq 5$ days/month or 6-10days/month) or the use of specific acute medication category (None, non- NSAID or triptan) with nonparametric rank-based methods for longitudinal data using the nparLD R package (v2.1) ${ }^{26}$. Descriptive point estimators of relative factor effect (RFE), confidence intervals and the ANOVA-type statistic (ATS) are reported. Nonparametric tests were chosen due to small sample sizes and because CGRP levels did not followed a normal distribution. 
medRxiv preprint doi: https://doi.org/10.1101/2020.11.18.20233841; this version posted November 18, 2020. The copyright holder for this preprint (which was not certified by peer review) is the author/funder, who has granted medRxiv a license to display the preprint in It is made available under a CC-BY-NC-ND 4.0 International license

A statistical power calculation was not conducted prior to the study because the sample size was based on the available data. P-values presented are for a two-tailed test and pvalues $<0.05$ were considered statistically significant.

Approval for this study was obtained from the Vall d'Hebron Ethics Committee (PR(IR)292/2017). All participants gave their consent for data collection.

\section{RESULTS}

\section{Descriptive}

In total, $22 \mathrm{EM}$ and $13 \mathrm{HC}$ with a mean age of $27.9 \pm 8.9$ years old were included (table 1 ). EM patients had statistically significant higher proportion of perceived stress $(95.5 \%$ vs. 46.2\%; $p=0.002$ ). Twelve patients (54.5\%) reported headache frequency of $\leq 5$ days/month and $45.4 \%$ (10/22) reported headache frequency of 6-10 days/month.

\section{Interictal CGRP levels}

We found statistically significant higher interictal CGRP-like immunoreactivity (CGRP-LI) salivary levels when comparing EM and mean basal HC values (98.0[86.7] vs. 42.2[44.7] $\mathrm{pg} / \mathrm{mL} ; \mathrm{p}=0.010$ ) (Fig. 1A). We did not find any correlation between CGRP-LI levels in regards to: age (rho=0.281, $p=0.102)$, HADS-A ( $r h o=0.282, p=0.101)$, HADS-D (rho=0.319, $p=0.062)$, or PSS score $(r h o=0.243, p=0.159)$. Although plasma CGRP-LI levels in EM patients were higher than $\mathrm{HC}$, we did not find statistically significant differences (EM: 6.1[5.0] vs. HC: $5.3[6.3] \mathrm{pg} / \mathrm{mL} ; \mathrm{p}=0.205$ ) (Fig. 1B). There was not a correlation between salivary and plasma CGRP-LI levels. 
medRxiv preprint doi: https://doi.org/10.1101/2020.11.18.20233841; this version posted November 18, 2020. The copyright holder for this preprint (which was not certified by peer review) is the author/funder, who has granted medRxiv a license to display the preprint in

It is made available under a CC-BY-NC-ND 4.0 International license

\section{Longitudinal analysis: salivary CGRP levels through migraine attack}

Amongst all patients, a total of 40 migraine attacks were collected. CGRP-LI concentration in saliva changed in a statistically significant way, in each timepoint considered of the attack, when analyzing all migraine attacks (pre:113.5[137.8], ictal:164.6[204.5], 2h:101.7[159.1], 8h:82.6[166.2], post:79.6[124.3] pg/ml; p<0.001) (Fig. 2).

When we analyzed the interaction between the migraine phase effect and headache frequency, we found that participants who reported headache frequency $\leq 5$ days/month had statistically significant smaller magnitude of change in CGRP-LI levels over the different migraine phases compared to those who reported 6-10 days/month (ATS $p=0.020$ ) (Fig. 3A). Nonetheless, this interaction did not reach the level of statistical significance between medicated attacks with neither non-steroidal anti-inflammatory drugs (NSAID) nor triptans even though it showed smaller magnitude of change in CGRPLI levels in triptan-treated attacks after migraine attack onset (ATS p=0.436) (Fig. 3B).

\section{Subtypes of migraine patients}

We found that $80.0 \%(32 / 40)$ were CGRP dependent (dCGRP) and 20.0\% (8/40) were nonCGRP dependent (nCGRP). When we compared interictal CGRP-LI levels between these two groups, no statistically significant differences were found; except for the onset of migraine attack (Oh), CGRP dependent group presented a statistically significant higher levels of CGRP-LI (dCGRP: 172.4 [252.1] vs. nCGRP: 60.9 [77.0]; $p<0.0001$ ). In regards to accompanying symptoms, a statistically significant association between photophobia (dCGRP: $81.3 \%$ vs. nCGRP: 37.5\%; $p=0.025$ ) and phonophobia (dCGRP: 75.0\% vs. nCGRP: 25.0\%; $p=0.014$ ) was found in dCGRP group. Dizziness (dCGRP: $34.4 \%$ vs. nCGRP: $75.0 \%$; 
medRxiv preprint doi: https://doi.org/10.1101/2020.11.18.20233841; this version posted November 18,2020 . The copyright holder for this preprint (which was not certified by peer review) is the author/funder, who has granted medRxiv a license to display the preprint in It is made available under a CC-BY-NC-ND 4.0 International license .

$p=0.047$ ) and vomiting (dCGRP: $3.1 \%$ vs. nCGRP: $37.5 \%$; $=0.020$ ) were statistically significantly associated with nCGRP group (table 2). When we analyzed migraine patients, 15 out of 22 patients only showed dCGRP migraine attacks; 4 out of 22 patients only showed nCGRP migraine attacks and only 3 patients showed both type of migraine attacks.

\section{DISCUSSION}

In this study, we performed an ELISA assay to measure and monitor salivary levels of CGRP in patients with very episodic and naïve migraine patients over the different migraine phases. We wanted to clearly see how attacks started and stopped, and avoid continuums of head pain. Compared to HC, EM patients showed higher interictal CGRP levels. However, intraindividually CGRP levels change during a migraine attack. Moreover, EM patients with clear migraine clinical symptoms can or can't have CGRP dependent attacks, creating subtypes of migraine patients, those who release CGRP during an attack and those who do not.

First, our results show that interictal salivary levels of CGRP are significantly higher in patients with EM, even if they suffer from infrequent attacks, compared to HC. Bellamy et al. also found that patients with EM had elevated salivary levels of CGRP between attacks compared to controls. ${ }^{13}$ There is only one previous study that found higher CGRP levels in $\mathrm{HC}$ probably due to participant's selection and procedures ${ }^{8}$. Other than saliva, previous studies using other substrates such as plasma ${ }^{27}$ or tear fluid ${ }^{28}$ also showed higher interictal levels of CGRP in patients with EM. Our finding reinforces that interictal 
medRxiv preprint doi: https://doi.org/10.1101/2020.11.18.20233841; this version posted November 18, 2020. The copyright holder for this preprint (which was not certified by peer review) is the author/funder, who has granted medRxiv a license to display the preprint in It is made available under a CC-BY-NC-ND 4.0 International license

salivary levels of CGRP are elevated in migraine patients, supporting its use as possible migraine diagnostic biomarker.

As a cycling brain disorder, monitoring migraine over its different phases is important in order to understand the underlying mechanisms and pathogenesis ${ }^{29}$, as it has been previously demonstrated in neuroimaging studies ${ }^{30}$. At the molecular level, our study reveals that salivary levels of CGRP change over a migraine attack according to the timepoint analyzed: they were shown to increase as headache progressed from preictal to the ictal phase and decreased in the postictal phase at or below interictal levels. Our results are the first ones to see this gradual change of CGRP levels during the attack, and confirm previous studies which also showed an increase in salivary levels of CGRP during the ictal phase, interpreting it as a distant sign of trigeminovascular activation ${ }^{8,16}$.This change reflects that CGRP levels may play a role as a dynamic biomarker in a disease that is not static which in turn strength the importance of monitoring migraine at different timepoints; and considering intraindividual change and not CGRP levels at a group level.

Regarding our longitudinal analysis, we observed that CGRP concentration was dependent on the migraine attack phase. We found an association between larger variations in CGRP concentration and higher headache frequency, which may support a greater activation of the trigeminovascular system in more severe forms of the disease 31,32. In this regard, controversial results have been published when CGRP levels were analyzed in serum samples. Cernuda-Morollón et al. ${ }^{33}$ found that CM patients exhibited the highest levels of CGRP, followed by EM patients and HC, suggesting it as a diagnostic biomarker of CM. In contrast, Lee et al. ${ }^{34}$ did not find any significant differences between 
medRxiv preprint doi: https://doi.org/10.1101/2020.11.18.20233841; this version posted November 18, 2020. The copyright holder for this preprint (which was not certified by peer review) is the author/funder, who has granted medRxiv a license to display the preprint in It is made available under a CC-BY-NC-ND 4.0 International license .

groups. Notwithstanding and taking this together, our results show that CGRP may serve as a biomarker of disease severity.

Based on our FC analysis, we also observed different types of patients: those with CGRP dependent and non-CGRP dependent migraine attacks. Some diagnostic migraine symptoms such as photo and phonophobia were significantly related to CGRP. This could be interesting both to understand the link between CGRP and migraine symptoms ${ }^{35}$, helping also to clinically predict CGRP treatment response according to the percentage of attacks with different symptoms. In this sense, it is worth mentioning the similarity found between the percentage of patients nCGRP dependent and non-responders' patients in clinical trials ${ }^{36}$. Moreover, since migraine diagnosis is currently based on clinical criteria according to the ICHD-3 ${ }^{19}$, our results supports the concept of classifying migraine from a pathophysiological point of view, ruling out some difficulties encompassed when a purely clinical diagnosis is done. This information might help us to carry out precision medicine.

Measuring CGRP closer to the afferents (saliva in our study) could be more effective than in plasma and is a reliable reflection of trigeminovascular activation ${ }^{28}$. We have found that levels of CGRP were higher in saliva than in plasma and there were not significant differences in plasma levels of CGRP between EM and HC. Hence, serum is not perhaps the ideal matrix to measure CGRP levels since neuropeptides are circulating in low concentrations in serum. As in previous studies, we did not find a correlation between salivary and plasma levels of CGRP $8,13,16$. During the past decades, saliva has received growing attention as a substrate to study biomarkers in chronic pain disorders ${ }^{37}$. Salivary 
medRxiv preprint doi: https://doi.org/10.1101/2020.11.18.20233841; this version posted November 18, 2020. The copyright holder for this preprint (which was not certified by peer review) is the author/funder, who has granted medRxiv a license to display the preprint in It is made available under a CC-BY-NC-ND 4.0 International license .

glands are innervated by the third branch of the trigeminal nerve and therefore are closer to the trigeminovascular system. These CGRP-containing trigeminal nerves release this neuropeptide in conditions such as migraine and cluster headache ${ }^{8}$.

Since the first demonstration of an increase in CGRP levels in external jugular venous blood during a migraine attack ${ }^{38}$, researchers have been seeking the most adequate technique to measure CGRP levels and, controversial results have been published possibly due to methodological differences. Our study, carried out with a rigorous methodology, strengthens the use of CGRP as a molecular biomarker, helping to diagnose the disease, correlate it with disease severity and predict treatment outcomes, which in turn would help manage both physician and patient expectations. It is now clear that CGRP plays a major role in migraine pathophysiology ${ }^{39,40}$, consolidated by the approval of new therapies targeting CGRP or its receptor ${ }^{41-43}$.

Deep phenotyping in migraine patients is an area of growing interest. Migraine is a complex neurological disease because of patient's heterogeneity and its underlying pathophysiology. Moreover, its dynamic character and cycling behavior with unpredictable attacks makes it more difficult to study in a static manner. For that reason, we monitored levels of CGRP through the different migraine phases and we found different types of migraine patients from a molecular point of view. Future research should be focused on finding a molecular, anatomical, genetical and physiological way of defining migraine which in turn could help to develop a pathophysiological driven classification. 
medRxiv preprint doi: https://doi.org/10.1101/2020.11.18.20233841; this version posted November 18, 2020. The copyright holder for this preprint (which was not certified by peer review) is the author/funder, who has granted medRxiv a license to display the preprint in It is made available under a CC-BY-NC-ND 4.0 International license

The study has some limitations. First, the small size of the sample. Some patients only collected one migraine attack so we need to be cautious when classifying patients into different types. However, we really wanted to include episodic migraine patients, in order to clearly differentiate the attack from the interictal period. Finally, most of the migraine attacks were treated. Thus, the majority of our CGRP levels were measured in medicated migraine attacks, proving that differences can be found even if we treat patients.

Our study has a longitudinal approach collecting samples over a 30-day period, which in migraine is very rare. This allowed us to analyze the CGRP profile in each migraine phase and each patient in a dynamic manner. Until now, saliva's studies published performed at patient's home, consisted of 1-2 days of saliva collection. Moreover, our study participants were strictly selected, without any history of previous preventive treatment use, amongst other characteristics, resulting in a very homogeneous sample.

In conclusion, our data show that CGRP levels vary according to the migraine phase, differentiating two types of patients from a pathophysiological point of view. The molecular profile of migraine might allow clinicians to better phenotype patients, may predict response to treatment and helps increase our understanding of migraine pathophysiology. 
medRxiv preprint doi: https://doi.org/10.1101/2020.11.18.20233841; this version posted November $18,2020$. The copyright holder for this preprint (which was not certified by peer review) is the author/funder, who has granted medRxiv a license to display the preprint in It is made available under a CC-BY-NC-ND 4.0 International license.

\section{Acknowledgement}

The authors thank the migraine patients who patiently followed all of our instructions for 30 days and they did not take any acute treatment until the first samples of the migraine attacks was collected.

This study was funded by a grant from Instituto de Salud Carlos III (ISCIII - PI16/01525) and Alicia Alpuente has been partially financed by a grant from the Headache Study Group of the Spanish Neurological Society 2018.

Authors' contributions. AA, VJG, MTF and PPR made substantial contributions to the conception and design of the study. LA made substantial contribution to the methodology and she performed the ELISA protocol. AA wrote first draft of the paper. VJG performed statistical analysis. All authors participated in acquisition, analysis and/or interpretation of data. All authors have critically revised and finally approved the version to be published.

Potential conflicts of interest: in relation with this paper the authors have nothing to disclose. 
medRxiv preprint doi: https://doi.org/10.1101/2020.11.18.20233841; this version posted November 18,2020 . The copyright holder for this preprint (which was not certified by peer review) is the author/funder, who has granted medRxiv a license to display the preprint in

\section{References}

1. FDA-NIH Biomarker Working Group. BEST (Biomarkers, EndpointS, and other Tools) Resource. Silver Spring (MD): Food and Drug Administration (US); Bethesda (MD): National Institutes of Health (US) 2016.

2. Stovner LJ, Nichols E, Steiner TJ et al. Global, regional, and national burden of migraine and tension-type headache, 1990-2016: a systematic analysis for the Global Burden of Disease Study 2016. Lancet Neurol $2018 ; 17: 954-76$.

3. Durham P, Papapetropoulos S. Biomarkers associated with migraine and their potential role in migraine management. Headache 2013;53:1262-77.

4. Ferroni P, Barbanti P, Spila A et al. New Opportunities For Precision Medicine. Curr Med Chem 2018;26:6191-6206.

5. Iyengar S, Johnson KW, Ossipov MH, Aurora SK. CGRP and the Trigeminal System in Migraine. Headache 2019;59:659-81.

6. Charles A, Pozo-Rosich P. Targeting calcitonin gene-related peptide: a new era in migraine therapy. Lancet 2019;394:1765-74.

7. Jasim H, Carlsson A, Hedenberg-Magnusson B et al. Saliva as a medium to detect and measure biomarkers related to pain. Sci Rep 2018;8:1-9.

8. Nicolodi M, Bianco E Del. Sensory Neuropeptides (Substance P, Calcitonin Gene-Related Peptide) and Vasoactive Intestinal Polypeptide in Human Saliva: Their Pattern in Migraine and Cluster Headache. Cephalalgia 1990;10:39-50.

9. Sicuteri F, Fanciullacci M, Nicolodi M et al. Substance P Theory: A Unique Focus on the Painful and Painless Phenomena of Cluster Headache. Headache 1990;30:69-79. 
medRxiv preprint doi: https://doi.org/10.1101/2020.11.18.20233841; this version posted November 18,2020 . The copyright holder for this preprint (which was not certified by peer review) is the author/funder, who has granted medRxiv a license to display the preprint in

10. Nicolodi M. Nostril capsaicin application as a model of trigeminal primary sensory neuronal activation. Cephalalgia 1990;14:134-8.

11. Dawidson I, Blom M, Lundeberg $\mathrm{T}$ et al. Neuropeptides in the saliva of healthy subjects. Life Sci 1996;60:269-78.

12. Nagano T, Takeyama M. Enhancement of salivary secretion and neuropeptide (substance $\mathrm{P}$, $\alpha$-calcitonin gene-related peptide) levels in saliva by chronic anethole trithione treatment. J Pharm Pharmacol 2001;53:1697-702.

13. Bellamy JL, Cady RK, Durham PL. Salivary levels of CGRP and VIP in rhinosinusitis and migraine patients. Headache 2006;46:24-33.

14. Jang MU, Park JW, Kho HS et al. Plasma and saliva levels of nerve growth factor and neuropeptides in chronic migraine patients. Oral Dis 2011;17:187-93.

15. Cady R, Turner I, Dexter K et al. An exploratory study of salivary calcitonin gene-related peptide levels relative to acute interventions and preventative treatment with onabotulinumtoxinA in chronic migraine. Headache 2014;54:269-77.

16. Cady RK, Vause C V., Ho TW et al. Elevated saliva calcitonin gene-related peptide levels during acute migraine predict therapeutic response to rizatriptan. Headache 2009;49:1258-66.

17. Domínguez C, Vieites-Prado A, Pérez-Mato M et al. CGRP and PTX3 as Predictors of Efficacy of Onabotulinumtoxin Type A in Chronic Migraine: An Observational Study. Headache 2018;58:78-87.

18. Andreasson U, Perret-Liaudet A, van Waalwijk van Doorn LJC et al. A practical guide to immunoassay method validation. Front Neurol 2015;6:1- 
medRxiv preprint doi: https://doi.org/10.1101/2020.11.18.20233841; this version posted November 18,2020 . The copyright holder for this preprint (which was not certified by peer review) is the author/funder, who has granted medRxiv a license to display the preprint in

8.

19. Headache Classification Committee of the International Headache Society. The International Classification of Headache Disorders, 3rd edition. Cephalalgia 2018;38:1-211.

20. Stewart WF, Lipton RB, Dowson AJ SJ. Development and testing of the Migraine Disability Assessment (MIDAS) Questionnaire to assess headache-related disability. Neurology 2001;S20-8.

21. M. Kosinski, M. S. Bayliss, J. B. Bjorner et al. A Six-Item Short-Form Survey for Measuring Headache Impact: The HIT-6TM. Qual Life Res 2003;12:963-74.

22. Snaith RP. The hospital anxiety and depression scale. Health Qual Life Outcomes 2003;1:6-9.

23. Cohen S, Kamarck T, Mermelstein R. A global measure of perceived stress. J Health Soc Behav 1983;24:385-96.

24. Lipton RB, Bigal ME, Ashina S et al. Cutaneous Allodynia in the Migraine Population. Ann Neurol 2008;63:148-58.

25. Buysse DJ, Reynolds CF, Monk TH et al. The Pittsburgh Sleep Quality Index: a new instrument for psychiatric practice and research. Psychiatry Res 1989;28:193-213.

26. Noguchi K, Gel YR, Brunner E, Konietschke F. nparLD : An R Software Package for the Nonparametric Analysis of Longitudinal Data in Factorial Experiments. J Stat Softw 2012;50.

27. Ashina $M$, Bendtsen $L$, Jensen $R$ et al. Evidence for increased plasma levels of calcitonin gene-related peptide in migraine outside of attacks. Pain 2000;86:133-8. 
medRxiv preprint doi: https://doi.org/10.1101/2020.11.18.20233841; this version posted November 18,2020 . The copyright holder for this preprint (which was not certified by peer review) is the author/funder, who has granted medRxiv a license to display the preprint in It is made available under a CC-BY-NC-ND 4.0 International license .

28. Kamm K, Straube A, Ruscheweyh R. Calcitonin gene-related peptide levels in tear fluid are elevated in migraine patients compared to healthy controls. Cephalalgia 2019;39:1535-43.

29. Dodick DW. A Phase-by-Phase Review of Migraine Pathophysiology. Headache 2018;58:4-16.

30. Schulte LH, May A. The migraine generator revisited: Continuous scanning of the migraine cycle over 30 days and three spontaneous attacks. Brain 2016;139:1987-93.

31. Seybold VS. The Role of Peptides in Central Sensitization. Handb Exp Pharmacol 2009:451-491.

32. Strassman AM, Raymond SA, Burstein R. Sensitization of meningeal sensory neurons and the origin of headaches. Nature 1996;384:356-8.

33. Cernuda-Morollón E, Larrosa D, Ramón C et al. Interictal increase of CGRP levels in peripheral blood as a biomarker for chronic migraine. Neurology 2013;81:1191-6.

34. Lee MJ, Lee SY, Cho S et al. Feasibility of serum CGRP measurement as a biomarker of chronic migraine: a critical reappraisal. J Headache Pain 2018;19:53.

35. Benarroch EE. CGRP: Sensory neuropeptide with multiple neurologic implications. Neurology 2011;77:281-7.

36. Broessner G, Reuter U, Bonner JH et al. The Spectrum of Response to Erenumab in Patients With Episodic Migraine and Subgroup Analysis of Patients Achieving $\geq 50 \%, \geq 75 \%$, and $100 \%$ Response. Headache 2020;60:2026-2040.

37. Fischer HP, Eich W, Russell IJ. A possible role for saliva as a diagnostic 
medRxiv preprint doi: https://doi.org/10.1101/2020.11.18.20233841; this version posted November $18,2020$. The copyright holder for this preprint (which was not certified by peer review) is the author/funder, who has granted medRxiv a license to display the preprint in It is made available under a CC-BY-NC-ND 4.0 International license .

fluid in patients with chronic pain. Semin Arthritis Rheum 1998;6:348-59.

38. Goadsby PJ, Edvinsson L, Ekman R. Vasoactive peptide release in the extracerebral circulation of humans during migraine headache. Ann Neurol 1990;28:183-7.

39. Edvinsson L, Warfvinge K. Recognizing the role of CGRP and CGRP receptors in migraine and its treatment. Cephalalgia 2019;39:366-73.

40. Edvinsson L. The Trigeminovascular Pathway: Role of CGRP and CGRP Receptors in Migraine. Headache 2017;57:47-55.

41. Silberstein SD, Dodick DW, Bigal ME et al. Fremanezumab for the Preventive Treatment of Chronic Migraine. N Engl J Med 2017;377:211322.

42. Tepper S, Ashina M, Reuter $U$ et al. Safety and efficacy of erenumab for preventive treatment of chronic migraine: a randomised, double-blind, placebo-controlled phase 2 trial. Lancet Neurol 2017;16:425-34.

43. Ho TW, Connor KM, Zhang $\mathrm{Y}$ et al. Randomized controlled trial of the CGRP receptor antagonist telcagepant for migraine prevention. Neurology 2014;83:958-66. 
medRxiv preprint doi: https://doi.org/10.1101/2020.11.18.20233841; this version posted November 18,2020 . The copyright holder for this preprint (which was not certified by peer review) is the author/funder, who has granted medRxiv a license to display the preprint in It is made available under a CC-BY-NC-ND 4.0 International license.

\section{TABLES}

Table 1. Baseline participants demographics, clinical characteristics and comorbidities.

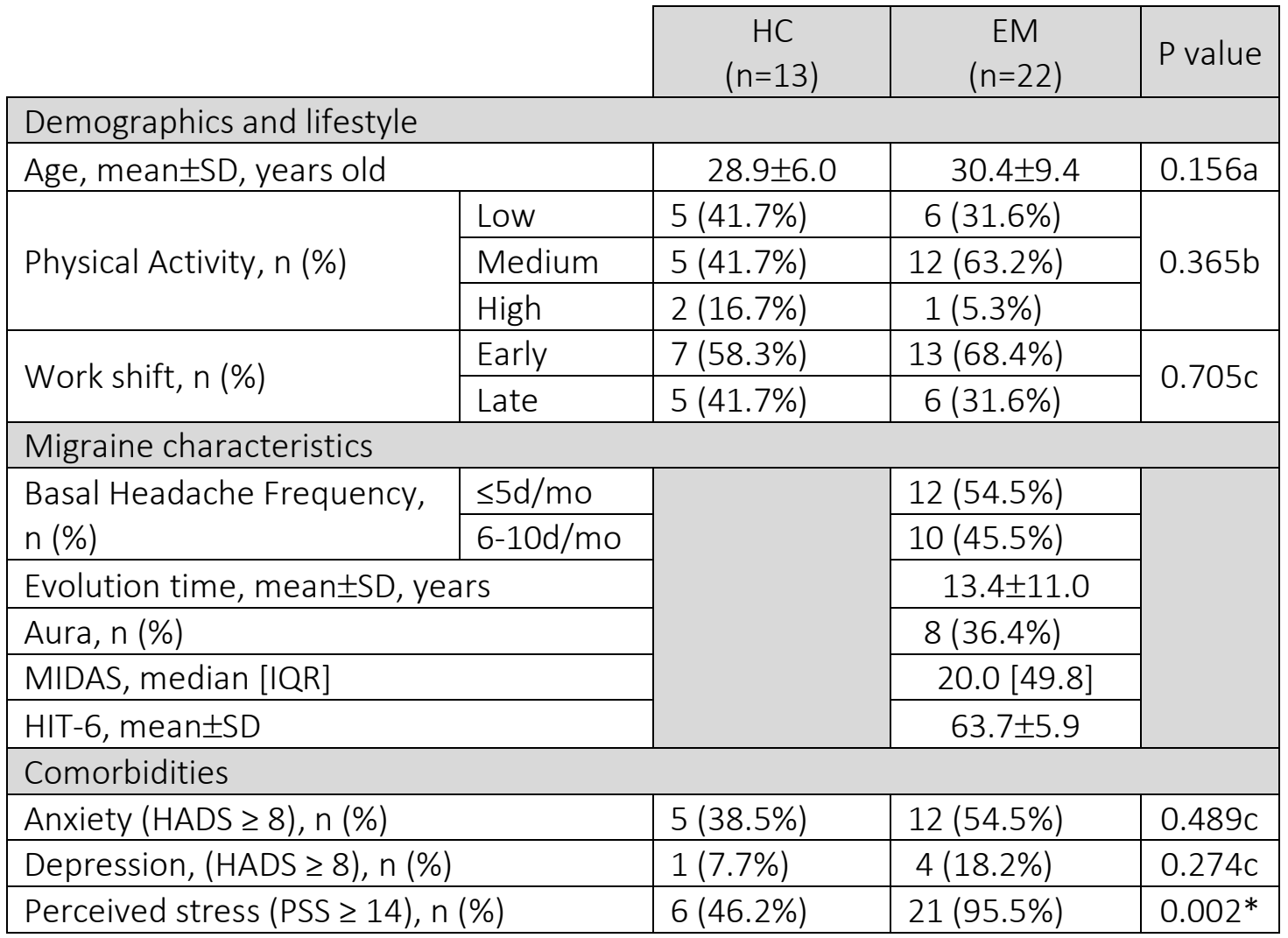

HC: Healthy Control; EM: Episodic Migraine; SD: Standard Deviation; IQR: Interquartile Range; HADS: Hospital Anxiety and Depression Scale; PSS: Perceived Stress Scale; d/mo: days/month.

alndependent T-test bLinear trend chi-squared cFisher's exact test

$* P$ value $\leq 0.01$ 
medRxiv preprint doi: https://doi.org/10.1101/2020.11.18.20233841; this version posted November 18,2020 . The copyright holder for this preprint (which was not certified by peer review) is the author/funder, who has granted medRxiv a license to display the preprint in It is made available under a CC-BY-NC-ND 4.0 International license

Table 2. Clinical parameters associated with dichotomic migraine attacks: CGRP dependent and non-CGRP dependent

\begin{tabular}{|l|c|c|c|}
\cline { 2 - 4 } \multicolumn{1}{c|}{} & $\begin{array}{c}\text { Non-CGRP } \\
\text { dependent } \\
(\mathrm{n}=8)\end{array}$ & $\begin{array}{c}\text { CGRP } \\
\text { dependent } \\
(\mathrm{n}=32)\end{array}$ & P value \\
\hline CGRP (Interictal)a, median [IQR] & $60.4[87.3]$ & $110.7[83.6]$ & 0.127 \\
\hline CGRP (Onset)a, median [IQR] & $60.9[77.0]$ & $172.4[252.1]$ & $<0.0001^{*}$ \\
\hline Treated attackb, n (\%) & $6(75.0 \%)$ & $17(53.1 \%)$ & 0.214 \\
\hline Aurab, $\mathrm{n}(\%)$ & $3(37.5 \%)$ & $5(15.6 \%)$ & 0.320 \\
\hline Unilateral Painb, n (\%) & $1(12.5 \%)$ & $8(25.0 \%)$ & 0.655 \\
\hline Nauseab, $\mathrm{n}(\%)$ & $5(62.5 \%)$ & $22(68.8 \%)$ & 1.000 \\
\hline Dizzinessb, $\mathrm{n}(\%)$ & $6(75.0 \%)$ & $11(34.4 \%)$ & $0.047^{*}$ \\
\hline Vomitingb, $\mathrm{n}(\%)$ & $3(37.5 \%)$ & $1(3.1 \%)$ & $0.020^{*}$ \\
\hline Photophobiab, $\mathrm{n}(\%)$ & $3(37.5 \%)$ & $26(81.3 \%)$ & $0.025^{*}$ \\
\hline Phonophobiab, $\mathrm{n}(\%)$ & $2(25.0 \%)$ & $24(75.9 \%)$ & $0.014^{*}$ \\
\hline Allodyniab, $\mathrm{n}(\%)$ & $6(75.0 \%)$ & $19(59.4 \%)$ & 0.686 \\
\hline
\end{tabular}

aMann-Whitney $U$ test

bFisher's exact test

$* p$ value $\leq 0.05$ 


\section{FIGURES}

Saliva

A

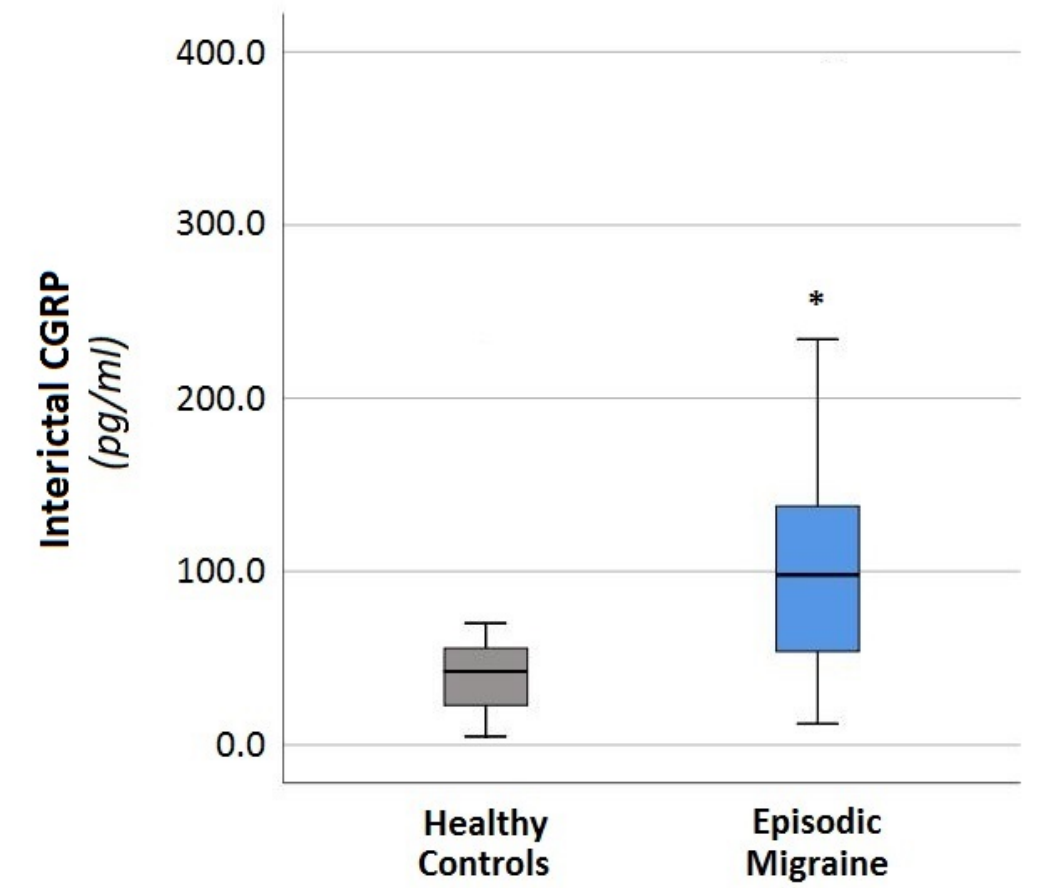

Plasma

B

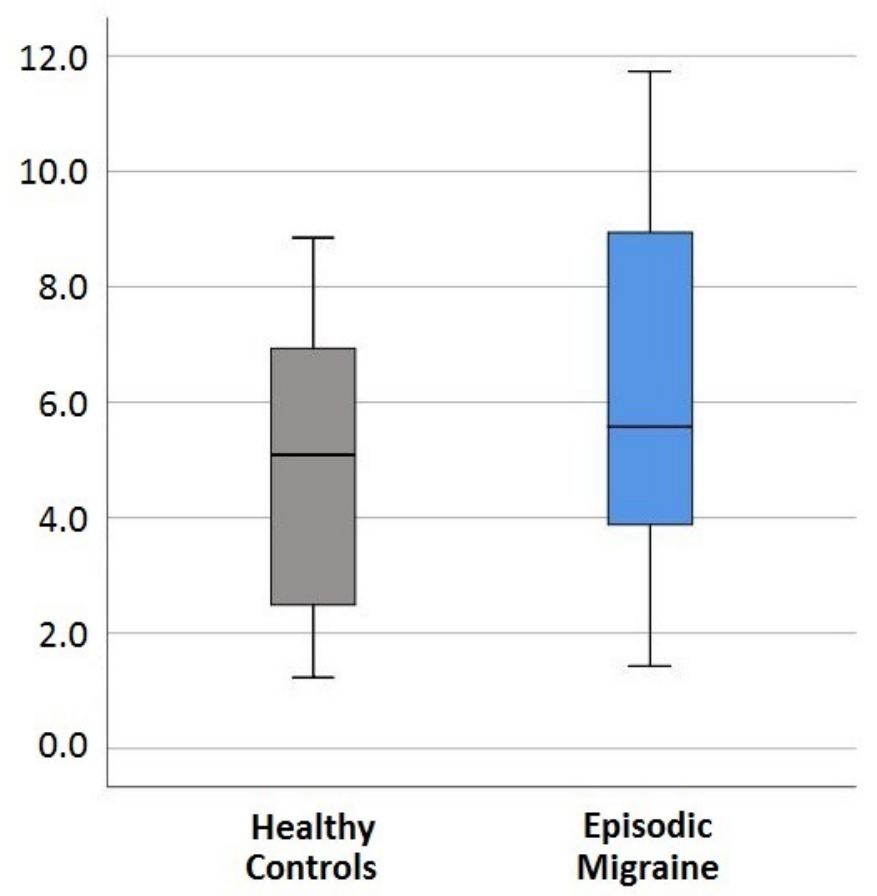

Figure 1. Interictal salivary levels of CGRP. Box plots and 95\% confidence intervals for interictal CGRP levels in saliva (A) and plasma (B). Interictal salivary levels of CGRP were calculated as the median value of 5 consecutive random days in healthy controls. In migraine patients, interictal salivary CGRP levels were calculated as the median value of 5 consecutive days when they were headache-free for 72 hours (interictal period). Plasma CGRP values were extracted during the screening, patients did not report a migraine attack during plasma blood extraction.

${ }^{*} p$ value $\leq 0.01$ 


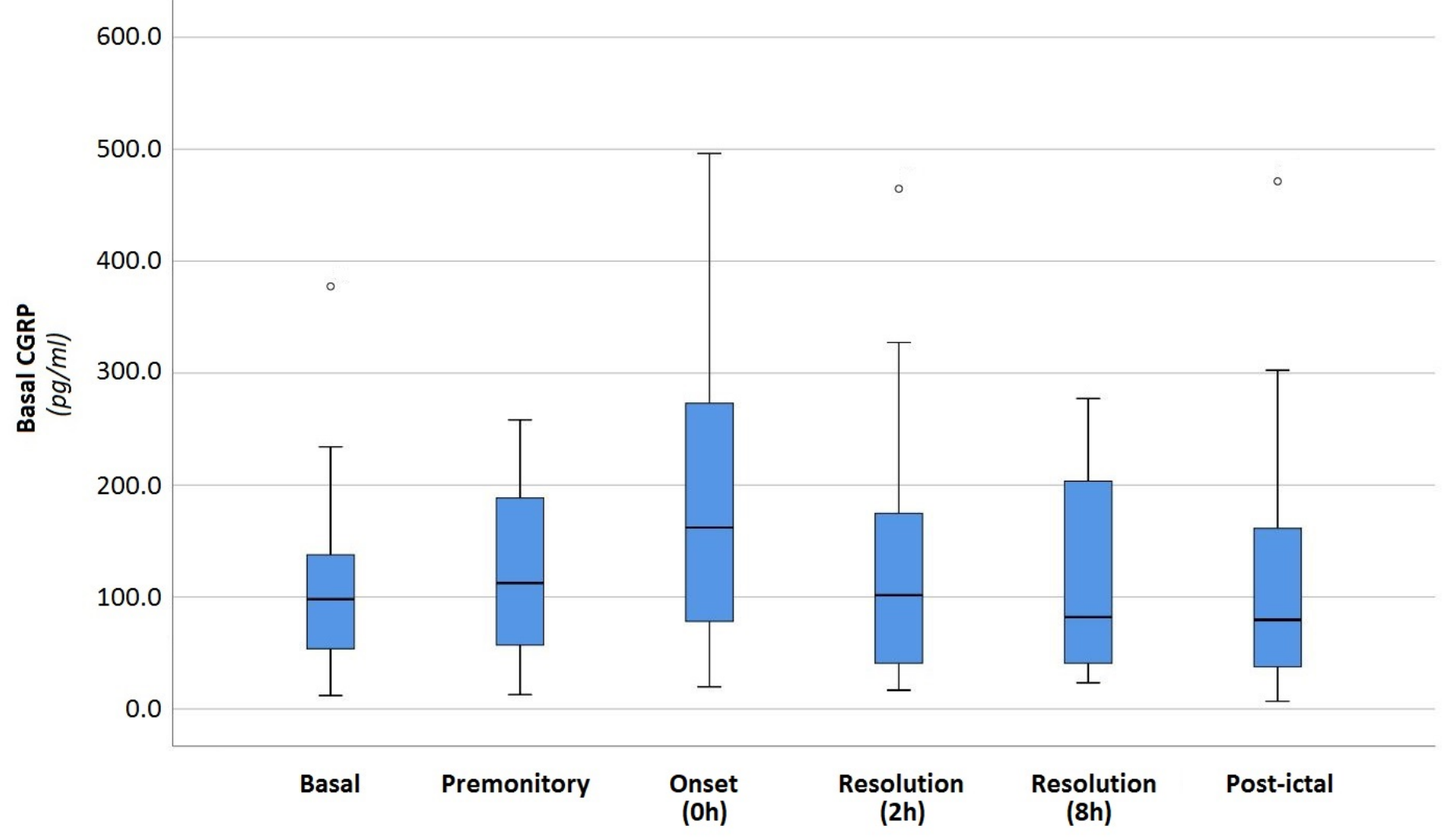

Figure 2. CGRP values through the different migraine phases. Box plots and 95\% confidence intervals for CGRP levels evolution in saliva according to patients' migraine phase. 
A

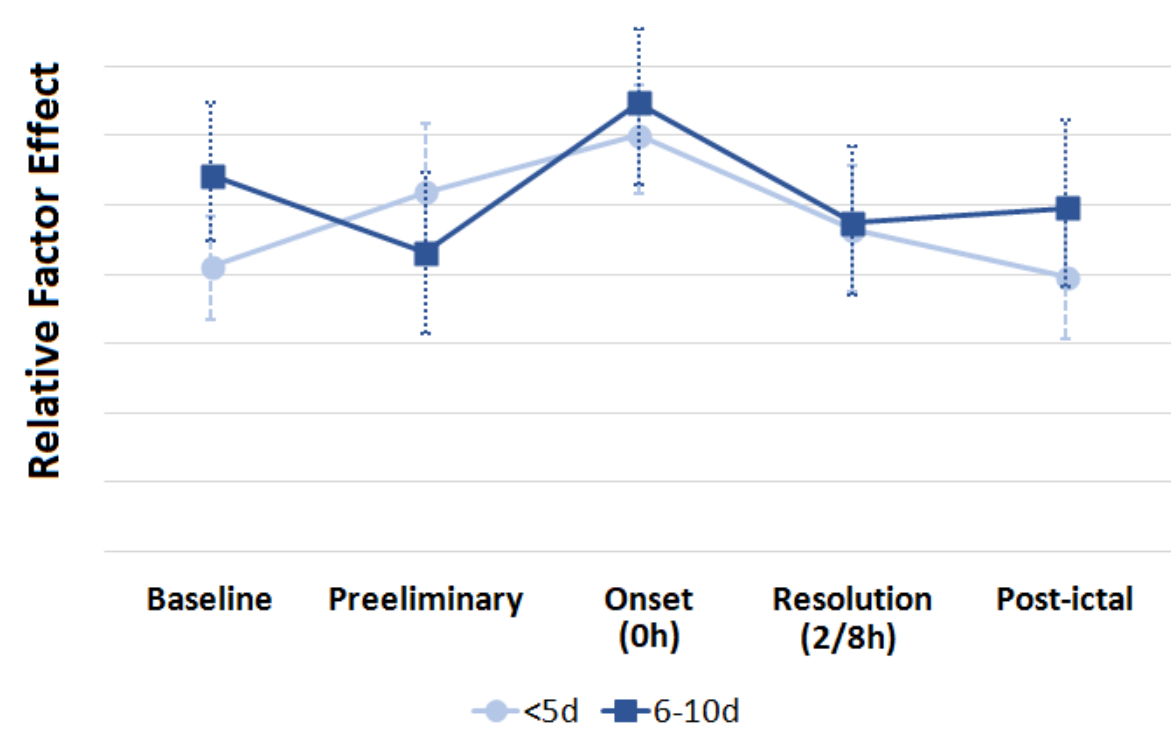

B

\section{Acute Medication Used}

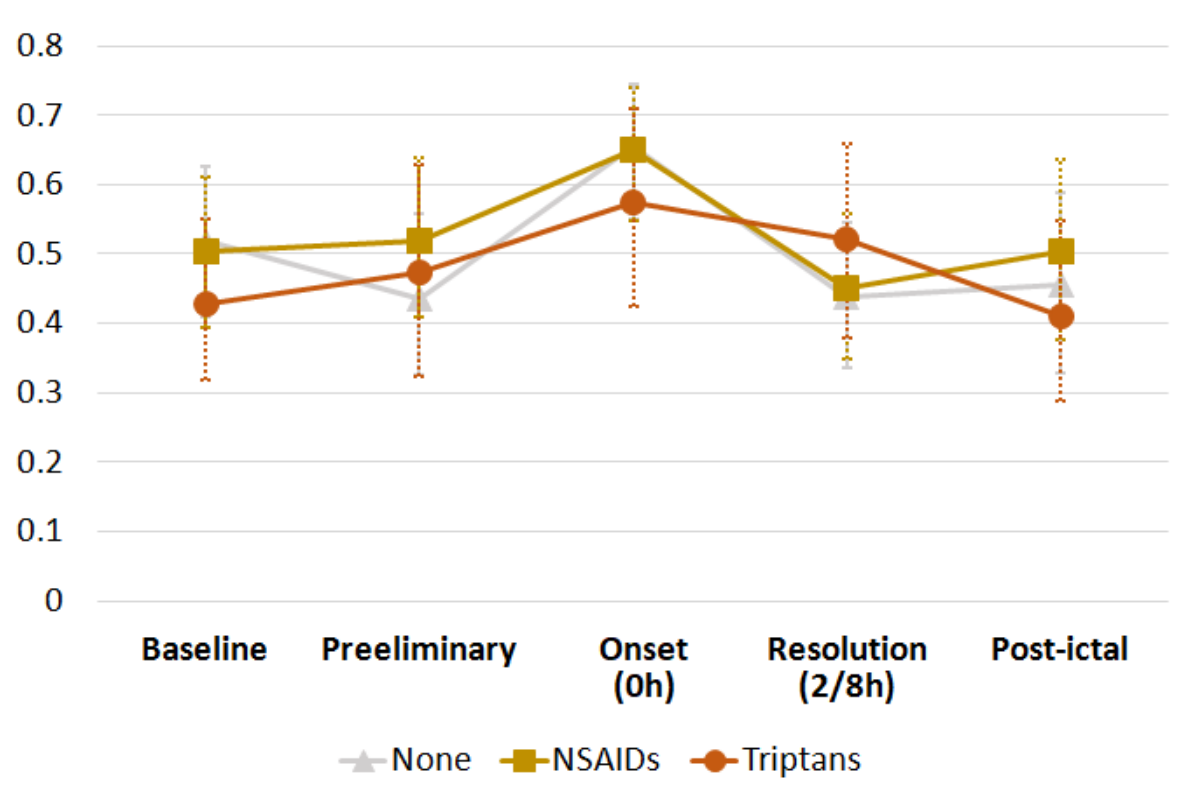

Figure 3. Interaction between the evolution in CGRP levels in the different migraine phases and (A) basal headache frequency or (B) acute treatment for migraine attacks. We studied the interaction between the migraine phase effect and the basal headache frequency $(A)$ and acute treatment (B) using rank-based nonparametric methods for longitudinal data. Only the interaction in the evolution of CGRP levels between the migraine phase and basal headache frequency was statistically significant. 